\title{
Praktik Pengalaman Lapangan
}

\author{
Studi Evaluatif Terhadap Kompetensi Mahasiswa PPL \\ PG PAUD Universitas Al Azhar Indonesia Tahun 2015/2016 \\ Nila Fitria ${ }^{1}$, Fidesrinur ${ }^{2}$ \\ ${ }^{1,2}$ Program Studi PG PAUD, Fakultas Psikologi dan Pendidikan, Universitas Al-Azhar Indonesia, \\ Jl.Sisingamangaraja, Kompleks Masjid Agung Al Azhar, Kebayoran Baru, Jakartan 12110 \\ Penulis untuk Korespondensi/E-mail: nilafitria@uai.ac.id
}

\begin{abstract}
Abstrak - Program Pengalaman Lapangan (PPL) merupakan salah satu mata pelajaran yang harus diikuti oleh setiap mahasiswa keguruan termasuk mahasiswa PAUD. Pelaksanaan mata pelajaran PPL berbeda dengan mata pelajaran lainnya yang diikuti di kelas atau dilaksanakan di kampus baik secara teori maupun praktik. Berbeda halnya mata pelajaran PPL adalah mata pelajaran dalam bentuk praktik pengalaman lapangan sebagaimana kegiatan guru di sekolahsekolah umumnya. Metode yang digunakan dalam penelitian ini adalah metode kualitatif (qualitative research). Penelitian ini menggunakan pendekatan deskriptif analitik, yaitu data dideskripsikan dengan menggunakan statistik deskriptif, dan dimaknai secara mendalam berdasarkan perspektif emik yaitu penyajian data secara alamiah tanpa melakukan suatu manipulasi atau perlakuan terhadap subjek yang diteliti (Bogdan dan Taylor, 1975:31). Kompetensi mahasiswa PPL meningkat ditandai dengan meningkatnya 4 kompetensi yaitu : kompetensi pedagogik, kompetensi kepribadian, kompetensi professional, dan kompetensi sosial. Pengetahuan yang dimiliki oleh mahasiwa PPL, guru pamong, dan dosen pembimbing memiliki peran yang sangat besar pengaruhnya dalam pelaksanaan PPL. Sedangkan peran kelompok PPL dan kepala sekolah kurang memiliki peran dalam pelaksanaan PPL.
\end{abstract}

Kata Kunci - Mahasiswa PPL, Kompetensi Pedagogik, Kompetensi Kepribadian, Kompetensi Profesional, Kompetensi Sosial

Abstract - Field Experience Program (PPL) is one of the subjects that should be followed by every student teacher including PAUD students. The implementation of PPL subjects is different from other subjects that are attended in class or held on campus in both theory and practice. In contrast to PPL subjects are subjects in the form of field experience practices as are the activities of teachers in general schools. The method used in this study is a qualitative method (qualitative research). This study uses descriptive analytic approach, which is descriptive descriptive data, and is interpreted in depth based on the perspective of emic that is the presentation of data naturally without doing a manipulation or treatment of the subjects studied (Bogdan and Taylor, 1975: 31). Competence of PPL students is marked by increasing the four competencies: pedagogic competence, personality competence, professional competence, and social competence. The knowledge that PPL students, pamong teachers, and lecturers have has an enormous role in PPL implementation. While the role of PPL groups and principals have less role in the implementation of PPL.

Keywords - PPL Students, Pedagogic Competence, Personality Competence, Professional Competence, Social Competence. 


\section{PENDAHULUAN}

\section{Latar Belakang}

Draktik Pengalaman Lapangan (PPL) Perupakan salah satu mata pelajaran yang harus diikuti oleh setiap mahasiswa keguruan termasuk mahasiswa PAUD. Pelaksanaan mata pelajaran PPL berbeda dengan mata pelajaran lainnya yang diikuti di kelas atau dilaksanakan di kampus baik secara teori maupun praktek. Berbeda halnya mata pelajaran PPL adalah mata pelajaran dalam bentuk praktek pengalaman lapangan sebagaimana kegiatan guru di sekolah-sekolah umumnya.

Pelaksanaan PPL yang akan diikuti oleh mahasiswa dilaksanakan paa tempat/lembaga yang berbeda-beda sehingga variasi sekolah tempat PPL juga bervariasi baik dalam kualitas pembelajaran maupun latar belakang anak yang sekolah di sekolah tersebut. Hal ini berarti bahwa masing-masing lembaga akan berbedabeda pula dalam pendekatan pembelajarannya. Perbedaan tersebut baik dalam bentuk kurikulum yang dipakai, pendekatan pembelajaran, maupun filosofi lembaga yang berbasis agama ataupun umum.

Berkaitan dengan tempat pelaksanaan PPL maka setiap lembaga mempunyai visi dan misinya masing-masing sesuai dengan filosofi yayasan atau lembaga perseorangan tersebut. Ada lembaga yang berbasiskan agama dan ada pula lembaga yang dikembangkan berbasis umum tidak berlandaskan agama tertentu. Masing-masing kekhasan lembaga tersebut akan tercermin dalam pelaksanaan lembaga dan sekaligus perwujudannya sebagai profil lulusan peserta didik yang dikembangkan.

Di samping pendekatan atau filosofi lembaga PAUD yang beragam maka variasi masingmasing lembaga PAUD tempat pelaksanaan PPL juga dipengaruhi oleh pelaksanaan kurikulum yang menjadi acuan dalam aktivitas pembelajaran. Diketahui bahwa lembaga PAUD baik TPA, Kelompok Bermain maupun TK (TK A/TK B) juga mempunayi acuan pembelajaraan yang beragam. Acuan tersebut baik dari menu generik, maupun dari KTSP 2004. Selain itu setelah terbitnya Permendikbud 146 tahun 2014 tentang Kurikulum 2013 PAUD maka acuan kegiatan pembelajaran pada lembaga-lembaga terpilih juga telah dilaksanakan. Perubahan ini tidak hanya berdampak pada acuan kurikulum yang diacu oleh masing-masing lembaga tetapi juga paradigma masing-masing lembaga terhadap pengembangan masing-masing kurikulum juga sangat bervariasi.

Selain itu sejak awal tahun 2000-an sosialisasi pendekatan pembelajaran di PAUD dikembangakan oleh Kemdiknas mengacu kepada pendekatan BCCT atas kerjasama Bank Dunia dengan Kemdiknas saat itu. Pendekatan masing-masing atas BCCT tidak hanya variatif sifatnya tetepi masing-masing sekolah tidak selalu mengacu pada satu pendekatan BCCT. Selain itu pendekatan pengelompokan belajar masing-masing sekoolah disamping dipengaruhi oleh fasilitas masing-masing lembaga PAUG yang sangat beragam. Keberagaman tersebut dapt diketahui dari pembelajaran yang berifat klasikal, pendekatan kelompok, area, sentra, atau bahkan ada yang bersifat individual. Sehingga kemampuan mengajar mahasiswa PPL menjadi perhatian program studi PG PAUD agar terampil dalam berbagai metode pembelajaran yang terus berkembang.

Semua keberagaman yang dikemukakan di atas berimplikasi kepada aktivitas masing-masing lembaga PAUD dimana mahasiswa malaksanakan PPL. Disisi lain pengembangan pembelajaran di perguruan tinggi mengacu kepada norma-norma akademik yang selalu berkembang sesuai dengan perkembangan ilmu tentang PAUD. Untuk memahami permasalahan PPL mahasiswa PAUD maka penelitian dengan judul PRAKTIK PENGALAMAN LAPANGAN Studi Evaluatif terhadap Kompetensi Mahasiswa PPL di PG PAUD Universitas Al Azhar Indonesia Tahun 2015/2016.

\section{Tujuan}

Berdasarkan latar belakang dan permasalahan di atas maka tujuan penelitian ini adalah sebagai berikut:

(1) Untuk menganalisis 4 kompetensi yang dimiliki mahasiswa PPL .

(2) Untuk menemukan factor-faktor yang mempengaruhi terhadap pelaksanaan PPL

\section{Perumusan Masalah}

Sehubungan dengan pembatasan masalah penelitian di atas, maka perumusan masalah pada penelitian ini adalah Bagaimanakah 
meningkatkan kompetensi mahasiswa PG PAUD melalui PPL?

\section{TINJAUAN PUSTAKA}

\section{Profesi Keguruan}

Tidak semua pekerjaan yang dilakukan disebut sebagai profesi. Profesi memerlukan syarat tertentu untuk disebut sebagai sebuah profesi karena profesi memerlukan pendidikan dan pelatihan khusus. Sejalan dengan itu Doyle (1990:24) mengemukakan bahwa profesi adalah suatu pekerjaan dimana anggotanya (pekerjaaannya) dianggap memeliki pengetahuan, keterampilan, tanggungjawab, layak dipercaya pada tingkat tinggi.

Dalam kaitan guru sebagai profesi menurut Lieberman (1956) mengemukakan bahwa profesi guru adalah sebagai berikut: (1) pelayanan adalah memfasilitasi pembelajaran bagaimana dapat terjadi dan apa yang diyakini merupakan kebutuhan oleh guru-guru berbeda sesuai dengan keyakinan, kebutuhan, dan pelaksanaannya bagi masing-masing masyarakat atau individu; (2) sebagai seorang praktisi dalam pelaksanaan tanggungjawab yang luas berdasarkan ertimbanganpertimbangan yang dibuat tindakan yang dilakukan dalam rangka otonomi profesional.

Selanjutnya profesionalisme seorang guru menurut Sutjipto (1194:42) perilaku guru dalam melaksanakan tugas sikap terhadap profesi guru yaitu sikap terhadap (1) peraturan perundang-undangan, (2) organisasi profesi, (3) teman sejawat, (4) peserta didik, (5) tempat kerja, (6) pemimpin dan (7) pekerjaan. Profesionalisme seorang guru ditentukan oleh perilaku guru dalam melaksanakan tugas, yaitu bagaimana penghayatan seorang guru tersebut dalam mengerjakan pekerjaan yang ditekuninya (Anderson, 1989:11).

\section{Praktik Pengalaman lapangan}

Untuk menjadi guru yang profesional, khususnya untuk mempersiapkan guru profesional dimulai dari proses belajar mengajar, dan praktek mengajar. Praktek mengajar atau Praktek Pengalaman lapangan (PPL) merupakan suatu upaya untuk memperkenalkan calon guru pada dunia profesinya. Melalaui PPL mahasiswa mengenal esensi kompetensi yang harus dimiliki oleh seorang guru. Pengalaman dalam PPL memberikan bekal bagi mahasiswa untuk mengenal dunia luar selain dunia akademis yang diperoleh di kampus. Selain itu keberagaman lembaga tempat praktek memeberikan pengalaman kepada mahasiswa bagaimana menyesuaikan diri dalam konteks akademik, sosial dan profesi dalam berbagai strata kehidupan.

Model PPL menurut Gagne dan kawan-kawan sebagai berikut: (1) guru memerlukan kesempatan dalam memperlihatkan kinerjanya dalam berbagai situasi, (2) guru memperoleh kesempatan dalam mengembangkan solusinya terhadap permasalahan, (3) sebagai seorang guru pemecahan masalah dipengaruhi oleh suatu kinerja yang terkait dengan pengetahuan yang diperlukan, (4) guru memerlukan umpan balik terhadap solusinya dari ahli dan juga mengamati bagaimana ahli tersebut dalam memecahkan masalah terhadap situasi tertentu, (5) menegetahui bahwa status kinerja sangat terkait dengan berbagai persoalan, (6) pemecahan masalah baik kognitif, pertimbangan terhadap berbagai kemungkinan pemecahan masalah sebelum memeutuskan untuk aplikasinya, (7) melaksanakan solusi terhadap suatu permasalahan yakni dengan melalkuan eksperimen bagaiana pemecahan masalah tersebut dapat dilaksanakan, dan (8) melakukan assesmen terhadap keefektifan solusi setelah dilaksanakan.

Menurut Yackulic (2001) ada tiga keterampilan yang diperlukan sesorang dalam mengajar yaitu (1) keterampilan disiplin ilmu, (2) keterampilan psiko paedagogik, dan (3) keterampilan pelengkap yang diperlukan dalam keterampilan mengajar. Untuk itu faktor-faktor yang dipertimbangkan sebagai komponen program pendidikan keguruan yaitu antara lain: (1) mengembangkan kebijakan dan program perencanaan dengan informasi penting yaitu komponen yang dapat diukur, (2) menyiapkan kerangka kerja untuk akuntabilitas program kepada pemangku kepentingan dan kepada masyaraka umunya, (3) menyiapkan kerangka kerja untuk diskusi jika diperlukan dan elemenelemen yang diperlukan guru untuk persiapan pendidik, dan (4) menyiapka kerangka kerja untuk diskusi sesuai dengan pengetahuan, keterampilan dan sikap guru atau pendidikan masa depan jika diperlukan. 
Sementara itu Reupert dan Woodcock (2010:1261) mengemukakan bahwa pengelolaan kelas merupakan pengetahuan yang sangat penting dalam melaksanakan pengalaman lapangan dan dalam melaksanakan profesi kependidikan. Selanjutnya O'neill dan Stephenson (2012:1131) mengemukakan hasil penelitian tentang PPL menurut sudut pandang kepala sekolah bahwa keterampilan pengelolaan kelas bagi guru pemula sangat penting. Hasil dari berbagai negara menunjukkan bahwa penguasaan pengelolaan kelas terkait dengan kepercayaan guru dalam praktek mengajar. Untuk itu persipan dalam mengelolaan perilaku harus menjadi perhatian serius bagi setiap guru.

Selain itu bagi guru pemula menurut Balli (2011:245) keyakinan yang dianut dalam belajar dapat menjadi penyangga dalam pengatahuan yang dimiliki dengan pelaksanaan pengajaran. Untuk itu ilmu pengetahuan yang diutamakan dalam pembelajaran perlu selalu diperbincangkan oleh guru dalam upaya mengembangkan pembelajaran dalam dunia pendidik.

\section{Kompetensi}

Becker and Ulrich dalam Suparno (2005:24) bahwa competency refers to an individual's knowledge, skill, ability or personality characteristics that directly influence job performance. Artinya, kompetensi mengandung aspek-aspek pengetahuan, ketrampilan (keahlian) dan kemampuan ataupun karakteristik kepribadian yang mempengaruhi kinerja. Bagi seorang guru, kompetensi mencakup aspek pengetahuan, ketrampilan, dan karakteristik kepribadian. kompetensi tersebut harus dimiliki oleh calon guru PAUD. Hal tersebut diperkuat oleh Spencer dan Spencer dalam Palan (2007) bahwa kompetensi adalah karakteristik dasar yang yang dimiliki oleh seorang individu. Terdiri dari 5 tipe karakteristik, yaitu motif (kemauan konsisten sekaligus menjadi sebab dari tindakan), faktor bawaan (karakter dan respon yang konsisten), konsep diri (gambaran diri), pengetahuan (informasi dalam bidang tertentu) dan keterampilan (kemampuan untuk melaksanakan tugas).

Menurut Permen No. 137 tahun 2013 pasal 25 ayat 2 menyatakan kompetensi guru PAUD dikembangkan secra utuh mencakup kompetensi pedagogic, kepribadian, sosial, dan professional.

\section{METODE}

Metode yang digunakan dalam penelitian ini adalah metode kualitatif (qualitative research). Bogdan dan Taylor (L.J Maleong, 2011:4) sebagai prosedur penelitian yang menghasilkan data deskripstif berupa kata-kata tertulis atau lisan dari orang-orang dan perilaku yang dapat diamati. Penelitian ini menggunakan pendekatan deskriptif analitik, yaitu data dideskripsikan dengan menggunakan statistik deskriptif, dan dimaknai secara mendalam berdasarkan perspektif emik yaitu penyajian data secara alamiah tanpa melakukan suatu manipulasi atau perlakuan terhadap subjek yang diteliti (Bogdan dan Taylor, 1975:31). Disamping itu data deskriptif yang diisi oleh pengurus dan pendidik PAUD diperkuat melalui triangulasi data melalui observasi dan wawancara pada pengurus dan pendidik PAUD, orang tua, dan masyarakat sekitar sekolah.

\section{Tempat dan Waktu Penelitian}

Penelitian dilaksanakan di lembaga PAUD tempat pelaksanaan PPL mahasiswa PG PAUD tahun 2015/2016. Sedangkan waktu penelitian berlangsung selama 7 (tujuh) bulan, yaitu dari bulan Januari 2016-Juli 2016.

\section{Ruang Lingkup dan Objek Penelitian}

Penelitian ini merupakan penelitian deskriptif kualitatif dengan ruang lingkup dan objek penelitian meliputi hal-hal sebagai berikut:

1. Lembaga PAUD tempat mahasiswa melaksanakan Praktek Pengalaman Lapangan (PPL)

2. Sasaran Penelitian adalah guru pamong, mahasiswa dan dosen pembimbing PPL

\section{Teknik Pengumpul Data}

Dalam pengumpulan data yang digunakan dalam penelitian ini adalah :

1. Observasi (pengamatan)

Observasi adalah bagian dalam pengumpulan data. Observasi berarti mengumpulkan data langsung dari lapangan (J.R. Raco, 2010:112) 
2. Wawancara

Wawancara dilakukan untuk memperoleh data yag tidak didapatkan di lapangan. Wawancara yang dilakukan kepada guru pamong, dosen pembimbing dan mahasiswa ditujukan untuk memperoleh data yang mendalam.

3. Kuesioner

Kuesioner atau survai adalah teknik pengumpulan data yang sangat popular dalam penelitian deskriptif (Alwasilah, 2000: 151). Kuesioner ini dalam bentuk pertanyaan terbuka yang akan dijawab oleh mahasiswa PG PAUD.

\section{Pengolahan dan Analisis Data}

Berdasarkan data primer dan data sekunder yang diperoleh, maka pengolahan data selanjutnya diolah dan analisis dengan menggunakan analisis:

1. Analisis Statistik Deskriptif: data angket yang diisi oleh responden dianalisis dengan statistik deskriptif guna melihat kecenderungan data tentang pesrsepsi responden.

2. Analisis Kualitatif: data hasil analisis statistik deskriptif selanjutnya dijelaskan secara kualitatif melalui hasil deskripsi observasi dan wawancara dengan responden.

\section{HASIL DAN PEMBAHASAN}

Pada bab ini akan dibahas hasil dan pembahasan penelitian. Penelitian ini bertujuan untuk mengetahui kesiapan mahasiswa dalam pelaksanaan PPL serta faktor-faktor yang mempengaruhinya baik itu kompetensi pedagogic, kompetensi kepribadian, kompetensi social, dan kompetensi kepribadian. Penelitian ini diberikan kepada mahasiswa-mahasiswa PG PAUD semester VII yang melaksanakan mata kuliah praktek pengalaman lapangan. PPL dilaksanakan di tiga taman kanak-kanak.

\section{Gambaran Umum}

Gambaran umum dari ketiga sekolah yang berada di bawah Yayasan Pesantren Islam Al Azhar yang terdiri dari TK Islam Al Azhar Pusat yang beralamatkan di Jaln Sisingamangaraja, Kebayoran Baru Jakarta Selatan, TK Al Azhar Pusat memiliki 1 kepala
TK, 18 guru, dan 3 orang tenaga administrasi. TK Islam Al Azhar Bintaro yang beralamatkan di Jalan Imam Bonjol, Bintaro Tangerang Selatan, memiliki 1 kepala TK, 12 guru, dan 2 orang tenaga administrasi dan TK Islam Al Azhar Pasar Minggu yang beralamatkan di Jalan Mujair No. 1 Pasar Minggu Jakarta Selatan, memiliki 1 kepala TK, 10 guru, dan 2 orang tenaga administrasi.

Standar pendidik guru TK di YPI Al Azhar dengan kualifikasi akademik guru PAUD memiliki ijazah Diploma empat (D IV) atau Sarjana (S1) dalam bidang PAUD dari program studi terakreditasi, hafal bacaan solat dan artinya, hafal surat-surat pendek dan doa harian. Kompetensi guru dikembangkan mencakup kompetensi pedagogic, kepribadian, sosial, dan profesional. Setelah lulus secara administrasi, calon guru mengikuti tes tertulis dan wawancara. Setelah lulus tes tersebut calon guru melakukan microteaching selama 1 bulan di TK yang telah ditentukan oleh bagian kepegawaian.

\section{Gambaran Khusus}

Gambaran Khusus Kompetensi Guru

Adapun gambaran khusus dari kompetensi yang harus dimiliki guru PAUD sebagaimana yang tercantum dalam Peraturan Menteri Pendidikan dan Kebudayaan RI Nomor 137 Tahun 2013 tentang Standar Nasional Pendidikan Anak Usia Dini Bab VII tentang Standar Pendidik dan Tenaga Kependidikan pasal 25 terkait.

1. Kualifikasi akademik guru PAUD: a. memiliki ijazah Diploma empat (D-IV) atau Sarjana (S1) dalam bidang pendidikan anak usia dini yang diperoleh dari program studi terakreditasi atau b. memiliki ijazah diploma empat (D-IV) atau sarjana (S1) kependidikan lain yang relevan atau psikologi yang diperoleh dari program studi terakreditasi dan memiliki setifikat Pendidikan Profesi Guru (PPG) PAUD dari perguruan tinggi yang terakrditasi.

2. Kompetensi guru PAUD dikembangkan secara utuh mencakup kompetensi pedagogic, kepribadian, sosial, dan profesional.

Adapun sub kompetensi pendidik yang tercantum dalam Peraturan Menteri Pendidikan dan Kebudayaan RI Nomor 137 tahun 2014 tentang Standar Nasional PAUD (terlampir) 


\section{Gambaran Khusus Kompetensi Mahasiswa PPL}

Hasil wawancara yang dilakukan kepada 2 narasumber dengan inisial LL dan LS. Wawancara dengan narasumber LL dilaksanakan pada 2 Maret 2016. Wawancara dengan narasumber LS dilaksanakan pada hari Jumat, 17 Juni 2016. Data yang tidak peroleh melalui wawancara, peneliti peroleh dari kuisoner yang dilakukan kepada mahasiswa PPL. dilengkapi dengan data hasil observasi langsung secara partisipatif yang dilakukan rentang waktu pada bulan Februari sampai dengan April. Untuk memperkuat substansi data hasil wawancara dan observasi, maka dilakukanlah penelusuran terhadap 11 dokumen dan arsip yang ada.

Dalam gambaran khusus ini, peneliti membagi menjadi 4 kompetensi yang tercantum didalam PERMEN DIKBUD RI No. 137 tahun 2013 yaitu:

\section{Kompetensi Pedagogik}

Kompetensi pedagogik memiliki 11 kompetensi yang harus dimiliki oleh guru PAUD, dimana masing-masing kompetensi tersebut memiliki sub kompetensi sendiri. Kompetensi guru PAUD dalam mengorganisasikan aspek perkembangan sesuai karakteristik anak usia dini dalam sub kompetensi; menelaah aspek perkembangan sesuai dengan karakteristik anak usia dini mendapatkan pengetahuan sebanyak $90 \%$ dari guru pamong, $80 \%$ dari kelompok PPL dan Pembimbing PPL, 70\% dari mahasiswa PPL dan $40 \%$ dari kepala sekolah. Sub kompetensi mengelompokkan anak usia dini sesuai dengan kebutuhan pada berbagai aspek perkembangan mendapatkan pengetahuan sebanyak $90 \%$ dari guru pamong, $70 \%$ pembimbing PPL, 30\% dari mahasiwa PPL, $20 \%$ dari kelompok dan kepala sekolah. Sedangkan sub kompetensi mengidentifikasi kemampuan awal anak usia dini dalam berbagai bidang pengembangan mendapatkan pengetahuan sebanyak 90\% dari guru pamong, $80 \%$ mahasiwa ppl, $70 \%$ dari kepala sekolah, $50 \%$ dari pembimbing PPL, $40 \%$ dari kelompok PPL. Untuk sub kompetensi mengidentifikasi kesulitan anak usia dani dalam berbagai bidang pengembangan mendapatkan pengetahuan sebanyak $90 \%$ guru pamong, $80 \%$ dari mahasiwa PPL,
40\% dari pembimbing PPL, 20\% kelompok PPL dan kepala sekolah.

Kompetensi menganalisis teori bermain sesuai aspek dan tahapan perkembangan, kebutuhan, potensi, bakat, dan minat anak usia dini dalam sub kompetensi memahami berbagai teori belajar dan prinsip-prinsip bermain sambil belajar yang mendidik yang terkait dengan berbagai bidang pengembangan di PAUD mendapatkan $90 \%$ pengetahuan dari pembimbing PPL, 80\% dari mahasiswa PPL dan guru pamong, 20\% dari kepala sekolah dan kelompok PPL. Sub kompetensi menelaah teori pembelajaran dalam konteks bermain dan belajar yang sesuai dengan kebutuhan aspek perkembangan anak usia dini mendapatkan 90\% dari mahasiswa PPL dan $80 \%$ dari pembimbing PPL, 70\% dari guru pamong dan $40 \%$ dari kepala sekolah dan kelompok PPL. Sedangkan sub kompetensi menerapkan berbagai pendekatan, strategi, metode, dan teknik bermain sambil belajar yang bersifat holistik, sesuai kebutuhan anak usia dini, dan bemakna, yang terkait dengan berbagai bidang pengembangan di PAUD mendapatkan informasi lebih banyak 80\% dari mahasiswa PPL,pembimbing dan guru pamong, 30\% dari kelompok PPL dan kepala sekolah. Sub kompetensi dalam merancang kegiatan bermain sebagai bentuk pembelajaran yang mendidik pada anak usia dini mendapatan 90\% dari guru pamong, $80 \%$ dari mahasiswa PPL, 50\% dari kelompok PPL dan pembimbing PPL, 10\% dari kepala sekolah.

Kompetensi merancang kegiatan pengembangan anak usia dini berdasarkan kurikulum membagi beberapa sub kompetensi. Sub kompetensi dalam menyusun isi program pengembangan anak sesuai dengan tema dan kebutuhan anak usia dini pada berbagai aspek perkembangan mendapatkan pengetahuan $90 \%$ dari guru pamong, 80\% dari mahasiswa PPL, 30\% dari kelompok PPL, dan pembimbing PPL, $20 \%$ dari kepala sekolah. Sub kompetensi dalam membuat rancangan kegiatan bermain dalam bentuk program tahunan, semester, mingguan, dan harian mendapatkan pengetahuan $90 \%$ dari guru pamong, 80\% dari mahasiswa PPL, 50\% dari pembimbing PPL, 20\% dari kelompok PPL, dan kepala sekolah. 
Kompetensi menyelenggarakan kegiatan pengembangan yang mendidik membagi sub kompetensi kemampuan dalam memilih prinsip-prinsip pengembangan yang mendidik dan menyenangkan menapatkan pengetahuan $90 \%$ dari guru pamong, $80 \%$ dari mahasiswa PPL, $40 \%$ dari pembimbing PPL, 20\% dari kelompok PPL dan kepala sekolah. Sedangkan sub kompetensi merancang kegiatan pengembangan yang mendidik dan lengkap, baik untuk kegiatan di dalam kelas, maupun luar kelas mendapatkan pengetahuan $90 \%$ dari guru pamong, $80 \%$ dari mahasiswa PPL, $40 \%$ dari pembimbing PPL, $20 \%$ dari kelompok PPL dan kepala sekolah. Serta sub kompetensi menerapkan kegiatan bermain yang bersifat holistik, autentik, dan bermakna mendapatkan informasi $90 \%$ dari guru pamong, $40 \%$ dari pembimbing PPL, $20 \%$ dari mahasiswa PPL,kelompok dan kepala sekolah.

Kompetensi guru dalam memanfaatkan teknologi, informasi dan komunikasi untuk kepentingan penyelenggaraan kegiatan pengembangan yang mendidik memiliki sub kompetensi. Sub kompetensi memilih teknologi informasi dan komunikasi serta bahan ajar yang sesuai dengan kegiatan pengembangan anak usia dini mendapatkan pengetahuan $90 \%$ dari guru pamong, $80 \%$ dari mahasiswa PPL, $30 \%$ dari pembimbing PPL 20\% dari kepala sekolah dan kelompok PPL. Sub kompetensi menggunakan teknologi informasi dan komunikasi untuk meningkatkan kualitas kegiatan pengembangan yang mendidik mendapatkan pengetahuan $90 \%$ dari guru pamong, $80 \%$ dari mahasiswa PPL, $30 \%$ dari pembimbing PPL 20\% dari kepala sekolah dan kelompok PPL.

Kompetensi mengembangkan potensi anak usia dini untuk pengaktualisasian diri memiliki sub kompetensi dapat memilih sarana kegiatan dan sumber belajar pengembangan anak usia dini mendapatkan pengetahuan sebanyak $90 \%$ dari guru pamong, 50\% dari mahasiswa PPL, dan $40 \%$ kelompok PPL, $20 \%$ dari pembimbing PPL dan 10\% dari kepala sekolah. Sub kompetensi membuat media kegiatan pengembangan anak usia dini mendapatkan pengetahuan sebanyak $90 \%$ dari guru pamong, 80\% mahasiwa, $70 \%$ dari kepala sekolah, 50\% dari pembimbing PPL, 40\% dari kelompok PPL. Sedangkan sub kompetensi mengembangkan potensi dan kreatifitas anak usia dini melalui kegiatan bermain sambil belajar mendapatkan pengetahuan sebanyak $90 \%$ dari guru pamong, 80\% dari kelompok PPL dan Pembimbing PPL, 70\% dari mahasiswa PPL dan $40 \%$ dari kepala sekolah.

Kompetensi berkomunikasi secara efektif, empati, dan santun memiliki dua sub kompetensi. Sub kompetensi memilih berbagai strategi berkomunikasi yang efektif, empatik dan santun dengan anak usia dini mendapatkan 90\% pengetahuan dari guru pamong, $80 \%$ dari mahasiswa PPL, 40\% dari kelompok PPL, kepala sekolah, dan pembimbing PPL. Sedangkan sub kompetensi berkomunikasi secara efektif, empatik, dan santun dengan anak usia dini mendapatkan informasi sebanyak $90 \%$ dari guru pamong, $80 \%$ dari mahasiswa PPL, $50 \%$ dari pembimbing PPL, 20\% dari kepala sekolah dan kelompok PPL.

Kompetensi menentukan lingkup sasaran asesmen proses dan hasil pembelajaran pada anak usia dini memiliki beberapa sub kompetensi. Sub kompetensi memilih pendekatan, metode dan teknik asesmen proses dan hasil kegiatan pengembangan pada anak usia dini mendapatkan informasi 90\% dari guru pamong, $80 \%$ mahasiwa PPL, $70 \%$ dari kepala sekolah, 50\% dari pembimbing, $40 \%$ dari kelompok PPL. Sub kompetensi menggunakan prinsip dan prosedur asesmen proses dan hasil kegiatan pengembangan anak usia dini mendapatkan informasi $90 \%$ dari guru pamong, $80 \%$ mahasiwa PPL, $70 \%$ dari kepala sekolah, $50 \%$ dari pembimbing, $40 \%$ dari kelompok PPL. Sub kompetensi melakukan evaluasi proses dan hasil belajar mendapatkan pengetahuan $90 \%$ dari mahasiswa PPL, $80 \%$ dari guru pamong, $40 \%$ dari pembimbing PPL, $20 \%$ kelompok PPL dan kepala sekolah.

2. Kompetensi Kepribadian

Kompetensi kepribadian memiliki 3 kompetensi yang masing-masingnya memiliki sub kompetensi. Kompetensi 
bertindak sesuai dengan norma, agama, hukum, social, dan kebudayaan nasional Indonesia dengan dua sub kompetensi menghargai peserta didik tanpa membedakan agama yang dianut, suku, adat-istiadat, status sosial, daerah asal, dan jenis kelamin diperoleh $90 \%$ sudah memiliki pengetahuan tersebut yang diperolehnya dari bangku kuliah, 60\% mendapatkan informasi dari Guru Pamong, $30 \%$ mendapatkan informasi dari kelompok PPL, Pembimbing PPL, dan Kepala Sekolah. Sedangkan kemampuan bersikap sesuai dengan agama yang dianut, hukum, sosial, dan norma yang berlaku dalam masyarakat, serta kebudayaan nasional Indonesia yang beragam diperoleh dari $90 \%$ sudah mendapatkan pengetahuan selama mengikuti perkuliahan, $60 \%$ mendapatkan informasi dari guru pamong, dan $40 \%$ mendapatkan informasi dari kepala sekolah, dan $30 \%$ mendapatkan informasi dari pembimbing ppl dan kelompok PPL.

Kompetensi menampilkan diri sebagai pribadi jujur, berakhlak mulia, dan teladan bagi anak usia dini dan masyarakat memiliki sub komptensi. Kompetensi menampilkan diri sebagai pribadi yang mantap, stabil, dewasa, arif, bijaksana, dan berwibawa memiliki dua sub kompetensi. Sub kompetensi menampilkan diri sebagai pribadi yang mantap dan stabil, mendapatkan $90 \%$ sudah memiliki pengetahuan sendiri selama di bangku kuliah, 70\% pengetahuannya diperoleh dari guru pamong, $40 \%$ dari Pembimbing PPL, $20 \%$ dari kelompok PPL dan 10\% dari kepala sekolah. Sub kompetensi menampilkan diri sebagai pribadi yang dewasa, arif, bijaksana dan berwibawa $90 \%$ pengetahuannya sudah dimiliki dari mahasiswa PPL, $40 \%$ pengetahuannya di peroleh dari Guru Pamong, 20\% dari kelompok PPL dan kepala sekolah, $10 \%$ dari pembimbing PPL.

\section{Kompetensi Profesional}

Kompetensi professional memiliki 5 (lima) kompetensi dan sub kompetensi. Untuk kompetensi mengembangkan materi, struktur, dan konsep bidang keilmuan yang mendukung serta sejalan dengan kebutuhan dan tahapan perkembangan anak usia dini dengan sub kompetensi menelaah konsep dasar keilmuan bidang matematika, sains, bahasa, studi sosial, seni dan agama yang sesuai dengan kebutuhan, tahapan perkembangan dan psikomotorik anak usia dini pertanyaan ini mendapat informasi sebanyak $80 \%$ pengetahuan dimiliki dari mahasiswa PPL selama mengikuti perkuliahan, 60\% dari guru pamong, 20\% dari pembimbing PPL dan $10 \%$ dari kelompok PPL dan kepala sekolah. Sedangkan kemampuan mengorganisasikan konsep dasar ke-ilmuan sebagai alat, aktivitas dan konten dalam pengembangan anak usia dini data diperoleh sebanyak $80 \%$ pengetahuan dimiliki dari mahasiswa PPL selama mengikuti perkuliahan, 60\% dari pembimbing PPL, $50 \%$ dari guru pamong, $20 \%$ dari kelompok PPL, dan 105 dari kepala sekolah.

\section{Kompetensi Sosial}

Kompetensi sosial memiliki kompetensi yang tiap kompetensinya memiliki sub kompetensi. Kompetensi bersikap inklusif, bertindak objektif, serta tidak diskriminatif karena pertimbangan jenis kelamin, agama, ras, suku, kondisi fisik, latar belakang keluarga, dan status sosial ekonomi memiliki sub kompetensi bersikap inklusif dan objektif terhadap anak usia dini, teman sejawat dan lingkungan sekitar dalam melaksanakan pembelajaran, informasi tersebut diperoleh $70 \%$ dari mahasiswa PPL, 50\% dari guru pamong, 30\% dari kepala sekolah, 20\% dari kelompok PPL dan pembimbing PPL. Sub kompetensi bersikap tidak diskriminatif terhadap anak usia dini, teman sejawat, orang tua, dan masyarakat lingkungan sekolah diperoleh informasi sebanyak $80 \%$ dari mahasiswa PPL, 60\% dari guru pamong, 40\% dari pembimbing PPL, $30 \%$ dari pembimbing PPL, dan 20\% dari kepala Sekolah.

\section{Pembahasan Penelitian}

Penelitian ini memperlihatkan kesiapan mahasiswa PG PAUD dalam melaksanakan PPL. Untuk melihat kesiapan mahasiswa, maka peneliti akan membahasnya berdasarkan empat kompetensi yang harus dimiliki oleh calon guru PAUD.

\section{Kompetensi Pedagogik}

Terdapat 11 kompetensi yang menjabarkan kompetensi pedagogik. Pada kompetensi 
mengorganisasikan aspek perkembangan sesuai karakteristik anak usia dini semua sub kompetensi mendapat pengetahuan dan informasi $90 \%$ dari guru pamong. Guru pamong memiliki peranan yang besar dalam praktek pengalaman lapangan mahasiswa PAUD dalam kompetensi ini. Sedangkan kompetensi menganalisis teori bermain sesuai aspek dan tahapan perkembangan, kebutuhan, potensi, bakat, dan minat anak usia dini $83,3 \%$ pengetahuan dan informasi diperoleh dari pembimbing PPL. Pengetahuan akan teori bermain sesuai aspek merupakan salah satu mata kuliah yang harus dikembangkan dipraktekkan. Sehingga pengetahuan tersebut menjadi bermanfaat dalam praktek pengalaman lapangan. Kompetensi merancang kegiatan pengembangan anak usia dini berdasarkan kurikulum 90\% pengetahuan diperoleh dari guru pamong. Dimana pada prakteknya siswa mengikuti rencana pembelajaran sesuai dengan sekolah tempat mereka melakukan PPL.

Kompetensi menyelenggarakan kegiatan pengemabnagn yang mendidik $90 \%$ pengetahuan diperoleh dari guru pamong. Hal ini mendapat pengaruh dari kegiatan observasi yang dilakukan sebelum mahasiswa PPL melakukan PPL di sekolah tersebut. Sehingga mahasiswa PPL mengetahui pola yang ada di sekolah tersebut. Kompetensi memanfaatkan teknologi, informasi, dan komunikasi untuk kepentingan penyelenggaraan kegiatan pengembangan yang mendidik rata-rata 90\% pengetahuan dan informasi diperoleh dari guru pamong. Dimana mahasiswa PPL mengetahui hal apa saja yang berkaitan dengan penggunaan teknologi. Dikarenakan tidak semua sekolah yang memiliki teknologi canggih. Kompetensi mengembangkan potensi anak usia dini untuk pengaktualisasian diri rata-rata $90 \%$ pengetahuan dan informasi diperoleh dari guru pamong. Hal tersebut mendapat pengaruh besar dari observasi yang dilakukan oleh mahasiswa PPL.

Kompetensi berkomunikasi secara efektif, empati, dan santun memiliki rata-rata $90 \%$ mendapat pengetahuan dan informasi dari guru pamong. Mahasiswa PPL lebih banyak berkomunikasi kepada guru pamong untuk intu mereka dapat menerapkan kemampuan ini kepada anak, guru-guru di sekolah, dan orang tua dimana mahasiswa PPL mendapatkan pengetahuannya dari guru pamong. Kompetensi menyelenggarakan dan membuat laporan penilaian, evaluasi proses dan hasil belajar anak usia dini, mahasiswa PPL rata-rata $90 \%$ sudah memiliki pengetahuan akan kompetensi tersebut dari perkuliahan yang diikutinya.

Kompetensi menentukan lingkup sasaran asesmen proses dan hasil pembelajaran pada anak usia dini rata-rata memiliki 90\% kemampuan ini dari guru pamong dan mahasiswa PPL sudah memiliki pengetahuan ini yang diperolehnya dari bangku kuliah. Kompetensi menggunakan hasil penelitian, pengembangan dan evaluasi program untuk kepentingan pengembangan anak usia dini rata-rata $90 \%$ pengetahuan diperoleh dari guru pamong. Kompetensi melakukan tindakan reflektif, korektif, dan inovatif dalam meningkatkan kualitas dan hasil pengembangan anak usia dini dimana rata-rata 90\% mahasiswa PPL telah memiliki pengetahuannnya yang diperolehnya di bangku kuliah dan 90\% diperoleh dari guru pamong.

\section{Kompetensi Kepribadian}

Kompetensi kepribadian memiliki beberapa kompetensi yang mendukung kompetensi kepribadian. kompetensi bertindak sesuai dengan norma, agama, hukum, sosial, dan kebudayaan nasional Indonesia rata-rata 90\% pengetahuan yang daidapatkan mahasiswa diperoleh dari bangku kuliah. Sehingga mahasiswa dapat mengaplikasikannya di tempat PPL. Kompetensi menampilkan diri sebagi pribadi jujur, berakhlak mulia, dan teladan bagi anak usia dini dan masyarakat rata-rata 90\% mahasiswa PPL mendapatkan pengetahuan dari bangku kuliah. Sedangkan kompetensi menampilkan diri sebagi pribadi yang mantap, stabil, dewasa, arif, bijaksana, dan berwibawa rata-rata $90 \%$ mahasiswa PPL mendapatkan pengetahuan tersebut selam mereka duduk di bangku kuliah. Kompetensi menunjukkan etos kerja, tanggung jawab yang tinggi, rasa percaya diri, dan bangga menjadi guru rata-rata $90 \%$ mahasiswa PPL sudah mendapatkan 
pengetahuan dan informasi dari bangku kuliah.

\section{Kompetensi Profesional}

Dalam kompetensi professional terdapat 5 kompetensi diantaranya kompetensi mengembangkan materi, struktur, dan konsep bidang keilmuan yang mendukung serta sejalan dengan kebutuhan dan tahapan perkembangan anak usia dini rata-rata $80 \%$ pengetahuan dan informasi sudah didapatkan mahasiswa PPL di bangku perkuliahan. Kompetensi merancang berbagai kegiatan pengembangan secara kreatif sesuai dengan tahapan perkembangan anak usia dini rata-rata $90 \%$ pengetahuan di peroleh dari guru pamong dan $75 \%$ pengetahuan diperoleh dari mahasiswa selama mengikuti perkuliahan. Kompetensi mengembangkan keprofesionalan secara berkelanjutan dengan melakukan tindakan reflektif ratarata mahasiswa PPL mendapatkan pengetahuan $80 \%$ dari guru pamong. Guru pamong disini bukan hanya sebagai guru kelas, tetapi guru pamong juga bertindak sebagai fasilitator di dalam kelas bersama mahasiswa PPL.

4. Kompetensi Sosial

Kompetensi sosial berhubungan dengan interaksi antara guru dengansesama guru, guru dan orang tua, guru dan anak, serta hubungan guru dengan masyarakat. Kompetensi bersikap inklusif, bertindak objektif, serta tidak diskriminatif karena pertimbangan jenis kelamin, agama, ras, suku, kondisi fisik, latar belakang keluarga, dan status social ekonomi rata-rata $75 \%$ pengetahuan dan informasi diperoleh dari mahasiswa PPL selama mengikuti perkuliahan. Sedangkan kompetensi berkomunikasi secara efektif, empatik, dan santun dengan sesame pendidik, tenaga kependidikan, orang tua dan masyarakat rata-rata 705 pengetahuan dan informasi diperoleh dari guru pamong. Guru pamong juga menjadi orang tua ketika mahasiswa PPL berada di temapt dilaksanakannya PPL. Untuk itu guru pamong secara continue mengevaluasi setiap kegiatan yang dilakukan mahasiswa PPL.

\section{KESIMPULAN DAN SARAN}

\section{Kesimpulan}

Berdasarkan hasil wawancara, kuisoner, dan obeservasi yang dilaksanakan kepada mahasiswa PG PAUD yang melaksanakan program praktik lapangan (PPL).Mahasiswa PG PAUD yang melaksanakan program praktik lapangan di akhir semester merupakan calon guru PAUD. Di mana dalam PERMEN DIKBUD Nomor. 137 tahun 2013 tentang Standar PAUD. Setelah mengikuti PPL selama 2 bulan, kompetensi yang dimiliki mahasiswa PG PAUD meningkat. Ditandai dengan meningkatnya kompetensi mahasiswa berdasarakan 4 kompetensi diantaranya kompetensi pedagogik, rata-rata mahasiswa PPL mendapatkan pengetahuan dan informasi berkenaan dengan kemampuan belajar mengajar, menganalisisi teori bermain, pengembangan anak usia dini berdasarkan tema, kemampuan merancang kegiatan pengembangan anak usia dini, hingga kemampuan menyelenggarakan kegiatan pengembangan anak usia dini, dan kemampuan memanfaatkan teknologi, informasi, dan komunikasi mendapat pengaruh yang besar didapatkan mahasiswa PPL yaitu dari pengalamannya selama belajar di bangku kuliah.

Hal ini memperlihatkan bahwa mata kuliah di program studi PG PAUD harus dipertahankan dan ditingkatkan terutama untuk kegiatan praktek. Pengaruh yang besar didapatkan mahasiswa PPL selama mengikuti PPL dari guru pamong. Dikarenakan guru pamong bukan hanya sebatas guru kelas di mana mahasiswa PPL itu berlatih mengajar tetapi juga sebagai evaluator, fasilitator di mana mahasiswa PPL melaksanakan PPL.

Kompetensi Kepribadian meningkat mencakup 3 kompetensi yang mencakup kompetensi bertindak sesuai norma, agama, hukum, social, dan kebudayaan nasional Indonesia, kompetensi menampilkan diri sebagai pribadi jujur, berakhlak mulia, dan teladan bagi anak usia dini dan masyarakat, kompetensi menampilkan diri sebagai pribadi yang mantap, stabil, dewasa, arif, bijaksana, dan berwibawa, kompetensi menunjukkan etos kerja, tanggungjawab yang tinggi, rasa percaya diri, dan bangga menjadi guru. Kompetensi kepribadian mendapat pengaruh yang besar 
selama mahasiswa PPL mengikuti perkuliahan serta pengetahuan dan informasi diperoleh dari dosen pembimbing. Dosen pembimbing memberi peranan bukan hanya dalam bentuk administrative tetapi juga dalam hal ketrampilan mengajar dan semua yang berkenaan dalam pengajaran.

Kompetensi professional meningkat pada mahasiswa PG PAUD mencakup 3 kompetensi yang harus dimiliki oleh mahasiswa yaitu mengembangkan materi,struktur, dan konsep bidang keilmuan yang mendukung serta sejalan dengan kebutuhan dan tahapan perkembangan anak usia dini, merancang berbagi kegiatan pengembangan secara akreatif sesuai dengan tahapan perkembangan anak usia dini, mengembangkan keprofesionalan secara berkelanjutan dengan melakukan tindakan reflektif. Dari 3 kompetensi professional, mahasiswa PPL mendapatkan pengetahuan setiap kompetensi dari guru pamong, dosen pembimbing, dan pengetahuan yang diperolehnya selama di bangku kuliah.

Dalam kompetensi sosial terdapat beberapa kompetensi yang mendukung ketrampilan social seorang guru. Kompetensi itu mencakup kompetensi bersikap inklusif, bertindak objektif, serta tidak diskriminatif karena pertimbangan jenis kelamin, agama, ras, suku, kondisi fisik, latar belakang keluarga, dan status social ekonomi, kompetensi berkomunikasi efektif, empatik, dan santun dengan sesama pendidik, tenaga kependidikan, orangtua, dan masyarakat memperoleh pengaruh yang besar dari guru pamong dan pengetahuan yang diperolehnya selama berada di bangku kuliah. Mahasiswa PPL memili kesempatan untuk mematangkan ketrampilan dalam berhubungan sosial.

\section{Saran}

Berdasarkan hasil penelitian, ditemukan permasalahan yang belum terungkap. Untuk itu peneliti memberikan beberapa saran:

1. Peran dosen dalam menanamkan konsep diri kepada mahasiswa PPL bahwa dirinya sebagai seorang guru merupakan tahap awal yang harus ditanamkan.

2. Peran dosen dalam mengembangkan kompetensi pedagogic, kepribadian, professional, dan social.
3. Peran dosen dalam mengaplikasikan teori dalam bentuk praktek untuk meningkatkan ketrampilan mahasiswa PPL dalam kemampuan mengajar.

4. Mahasiswa harus mengembangkan seluruh potensinya agar dapat mewujudkan menjadi guru yang professional.

5. Program studi PG PAUD perlu melakukan evaluasi dan monitoring mata kuliah dan pelaksanaannya untuk melihat kesesuaiannya dalam pembelajaran.

\section{DAFTAR PUSTAKA}

[1] Anderson, Lorin W. The Effective Teacher: Study Guide and Reading, New York: Holt Rinehart and Winston, 1997

[2] Arce, Eve-Marie, Curriculum for Young : An Introduction (New York: Balli, Sandra J., Preservice Teachers' Episodic Memories of Classrooom Management, Journal Teaching and Teacher Education homepage:

www.elsevier.com/locate/tate. 2011. pp. 245-251

[3] Bredekamp, Sue dan Teresa Rosegrant, "Reaching Potentials: Introduction" Reaching Potentials: Appropriate Curriculum and Assessment for Young Children Volume 1 Editor Sue Bredekamp and Teresa Rosegrant, Washington: NAEYC, 1999.

[4] Bredekamp, Sue dan Teresa Rosegrant, "Reaching Potentials Through Appropriate Curriculum Conceptual Frameworks for Applying the Guidelines" Reaching Potentials: Appropriate Curriculum and Assessment for Young Children Volume 1 Editor Sue Bredekamp and Teresa Rosegrant, Washington: NAEYC, 1999.

[5] Doyle, W., Theme in Teacher Education Reaserach dalam W.R. Houston Handbook of Research on Teacher Education, New York: McMilland and Co., 1990.

[6] O'Neill, Sue and Jennifer Stephenson, Does Classroom Management Coursework Influence Pre-service Teachers' Perceived Preparedness or Confidence, Journal Teaching and Teacher Education homepage: 
www.elsevier.com/locateltate. 2012. pp. 1131-1143.

[7] Reupert, Andrea dan Stuart Woodcok, Success and Near misses: Pre-service Teachers'use, confidence and success in various classroom management strategies, Journal Teaching and Teacher Education homepage: www.elsevier.com/locate/tate . 2010. pp. 1261-1268
[8] Schickendanz, Judith A., dkk, Understanding Children and Adolescents Fourth Edition Boston: Allyn and Bacon, 2001.

[9] Sutjipto, Profesi Keguruan, Jakarta: Dirjendikti, Depdiknas, 1994.

[10] Zais, Robert S., Curriculum: Principles and Foundations New York: Harper and Row Publisher, 1976. 